\title{
Op weg naar professionaliteit
}

Zoals bekend vormen de rollen van het CanMEDS project - door het Centraal College Medisch Specialismen (CCMS) vertaald in competenties - één van de uitgangspunten van de modernisering van de vervolgopleidingen. Ieder specialisme heeft in een plan moeten aangeven welke competenties wanneer aan de orde komen. Dat heeft geleid tot lijvige documenten met een gedetailleerde inhoud waaraan 'het veld' nu gestalte moet geven. Beschrijven welke competenties bij welke onderdelen en welke leeractiviteiten belangrijk zijn is de eerste stap. Maar hoe onderwijs je competenties als communicatie, samenwerking, professionaliteit en hoe toets je of het vereiste niveau is gehaald?

Van Luijk en coauteurs geven een richting aan hoe professionaliteit valt te leren en te toetsen. Zij constateren terecht dat de definitie van professionaliteit onduidelijk is en zijn van mening dat de omschrijving van de professionele rol zoals CanMEDS die hanteert eenzijdig rust op ethische principes. Hoe belangrijk deze ook zijn, men doet daarmee onvoldoende recht aan specialistische kennis en vaardigheden zonder welke professionaliteit het niet kan stellen. Het artikel roept een interessante vraag op: kan professionaliteit gelden als eigenstandige competentie? Of moeten we, net als indertijd bij de competentie 'medisch handelen' onder ogen zien dat hier sprake is van een bundeling van kennis, kunde en ervaring die het medisch handelen steeds op bepaalde niveaus van ontwikkeling doordesemt? Het artikel van Van Luijk ondersteunt het tweede perspectief. Professionaliteit moet gezien worden als overkoepelende competentie, niet als één van de zeven. Dit is in lijn met de opvatting van het 'Royal College of Physicians of London': 'Medical professionalism lies at the heart of being a good doctor'. ${ }^{1} \mathrm{Zij}$ geven een kader aan waarmee uiteenlopende activiteiten op de werkvloer getoetst kunnen worden op professionaliteit. Daarbij neemt observatie op de werkvloer een belangrijke plaats in. Immers, professionaliteit in de beroepsuitoefening is afhankelijk van de context waarin het handelen plaatsvindt en bovendien cultureel en tijdsafhankelijk bepaald. Alleen door observatie kan onprofessioneel gedrag opgemerkt worden en adequate feedback is hierbij van onmisbare waarde. Een caveat bij het onderwijzen van professionaliteit is op zijn plaats.

Om de dokters-van-de-toekomst voor te bereiden op een professionele beroepsuitoefening in een samenleving waarin normen en waarden aan verandering onderhevig zijn, zal naast aandacht voor de arts-patiëntrelatie ook de relatie tussen de beroepsgroep en de samenleving een belangrijke plaats moeten innemen. ${ }^{2}$ Een interessante vraag is dan of professionaliteit in de individuele arts-patiëntrelatie inderdaad al, zoals de auteurs stellen, voor een groot deel gevormd wordt in de basisopleiding. Bevindt de medische student zich, ook in de coassistentschappen, niet nog te veel in de rol van lerende in algemene zin en te weinig in de rol van beroepsbeoefenaar-in-wording?

Mogelijk is de semi-artsstage, zoals die in enkele curricula reeds is ingebed, het 
meest geschikt om de professionele rol vorm te geven in de authentieke omgeving die daartoe is vereist.

Visser et al. maken zich zorgen over het kunnen realiseren van de keuzestage in het buitenland tijdens de vervolgopleiding daar het Opleidingsfonds van VWS sinds eind 2007 daarvoor geen middelen meer aan de arts in opleiding tot specialist (aios) beschikbaar stelt. Hun onderzoek onder aios kindergeneeskunde toont aan dat er grote belangstelling bestaat voor een buitenlandse stage waarbij de voorkeur uitgaat naar een periode van zes maanden en dan liefst in een ontwikkelingsland. Vrijwel alle competenties komen bij een dergelijke stage aan bod en dat maakt dat de buitenlandse periode een waardevolle aanvulling is op het curriculum. Gelukkig gloort er hoop aan de horizon nu VWS inmiddels in een persbericht heeft laten weten dat de subsidie voor buitenlandse keuzestages als onderdeel van de specialistenopleiding vanaf 2010, onder voorwaarden, weer zal worden toegekend. Het zal afhangen van die voorwaarden of een dergelijke stage ook gevolgd kan worden in een ontwikkelingsland, want zelfs in de grote 'teaching hospitals' is het leerklimaat en de begeleiding door de stafspecialisten vaak van een andere orde dan de aios in Nederland ge- wend is, de goede uitzonderingen daargelaten. Deze tekortkomingen worden echter ruimschoots gecompenseerd door andere kwaliteiten die een stage in een ontwikkelingsland met zich mee brengt.

Goed nieuws voor docenten die de taak hebben tentamenvragen te maken. Paes en Ten Cate adviseren na retrospectief onderzoek de voorkeur te geven aan driekeuzevragen boven vier- of vijfkeuzevragen. Het vierde alternatief is vaak zo onwaarschijnlijk dat een groot deel van de studenten dit nimmer aankruist. Onderwijskundig is het aan te bevelen naast de meerkeuzevragen ook andere vraagvormen te gebruiken, zoals open vragen en (extended) matching-vragen. Maar als de opleiding kiest voor driekeuzevragen is daar voor de docent minder tijd mee gemoeid en kan de student in hetzelfde tijdsbestek meer vragen beantwoorden.

\section{Onno Terpstra}

\section{Literatuur}

1. Royal College of Physicians of London. Doctors in Society: Medical Professionalism in a Changing World. London: Royal College of Physicians of London; 2005.

2. Cruess SR, Cruess RL. Understanding medical professionalism: a plea for an inclusive and integrated approach. Med Educ 2008;42:755-757. 